LA W RENCE LIVERMORE N A TION AL LABORATORY

\title{
Metal-Containing Organic and Carbon Aerogels for Hydrogen Storage
}

J. H. Satcher, Jr., T. F. Baumann, J. L. Herberg

January 12, 2005 
This document was prepared as an account of work sponsored by an agency of the United States Government. Neither the United States Government nor the University of California nor any of their employees, makes any warranty, express or implied, or assumes any legal liability or responsibility for the accuracy, completeness, or usefulness of any information, apparatus, product, or process disclosed, or represents that its use would not infringe privately owned rights. Reference herein to any specific commercial product, process, or service by trade name, trademark, manufacturer, or otherwise, does not necessarily constitute or imply its endorsement, recommendation, or favoring by the United States Government or the University of California. The views and opinions of authors expressed herein do not necessarily state or reflect those of the United States Government or the University of California, and shall not be used for advertising or product endorsement purposes.

This work was performed under the auspices of the U.S. Department of Energy by University of California, Lawrence Livermore National Laboratory under Contract W-7405-Eng-48. 


\section{Metal-Containing Organic and Carbon Aerogels for Hydrogen Storage}

Tracking Number: 04-ERD-053

Principal Investigator: Joe H. Satcher, Jr.

Co-Investigators: Theodore F. Baumann, Julie L. Herberg

Overview. This document and the accompanying manuscript summarize the technical accomplishments of our one-year LDRD-ER effort. Hydrogen storage and hydrogen fuel cells are important components of the 2003 Hydrogen Fuel Initiative focused on the reduction of America's dependence on oil. To compete with oil as an energy source, however, one must be able to transport and utilize hydrogen at or above the target set by DOE $\left(6 \mathrm{wt} \% \mathrm{H}_{2}\right)$ for the transportation sector. Other than liquid hydrogen, current technology falls well short of this DOE target. As a result, a variety of materials have recently been investigated to address this issue. Carbon nanostructures have received significant attention as hydrogen storage materials due to their low molecular weight, tunable microporosity and high specific surface areas. For example, the National Renewable Energy Laboratory (NREL) achieved 5 to $10 \mathrm{wt} \% \mathrm{H}_{2}$ storage using metal-doped carbon nanotubes. That study showed that the intimate mix of metal nanoparticles with graphitic carbon resulted in the unanticipated hydrogen adsorption at near ambient conditions. The focus of our LDRD effort was the investigation of metal-doped carbon aerogels (MDCAs) as hydrogen storage materials. In addition to their low mass densities, continuous porosities and high surface areas, these materials are promising candidates for hydrogen storage because MDCAs contain a nanometric mix of metal nanoparticles and graphitic nanostructures. For FY04, our goals were to: (1) prepare a variety of metal-doped CAs (where the metal is cobalt, nickel or iron) at different densities and carbonization temperatures, (2) characterize the microstructure of these materials and (3) initiate hydrogen adsorption/desorption studies to determine $\mathrm{H}_{2}$ storage properties of these materials. Since the start of this effort, we have successfully prepared and characterized $\mathrm{Ni}$ - and Co-doped carbon aerogels at different densities and carbonization temperatures. The bulk of this work is described in the attached manuscript entitled "Formation of Carbon Nanostructures in Cobalt- and NickelDoped Carbon Aerogels". This one-year effort has lead to our incorporation into the DOE Carbon-based Hydrogen Storage Center of Excellence at NREL, with funding from DOE's Energy Efficiency and Renewable Energy (EERE) Program starting in FY05.

Work was performed under the auspices of the U.S. Department of Energy by Lawrence Livermore National Laboratory under contract number W-7405-ENG-48. The project (04-ERD053) was funded by the Laboratory Directed Research and Development Program at LLNL. 